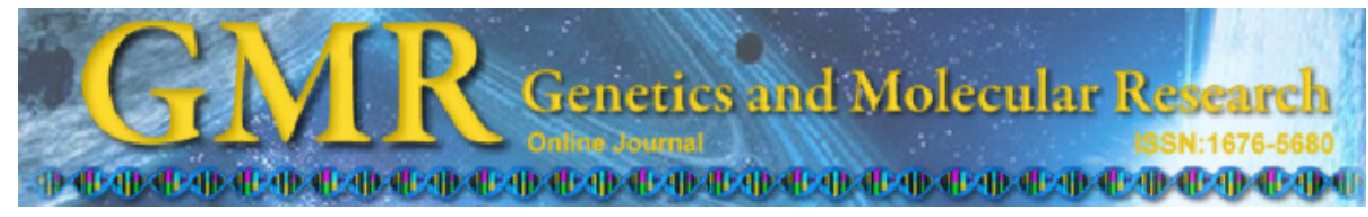

Methodology

\title{
Simplified preparation of a DNA ladder using PCR
}

\author{
T.-Y. Wang, L. Wang and F. Wang \\ Department of Biochemistry and Molecular Biology, \\ Xinxiang Medical University, Henan, P.R. China
}

Corresponding author: T.-Y. Wang

E-mail: wtianyuncn@126.com

Genet. Mol. Res. 10 (3): 1631-1635 (2011)

Received November 29, 2010

Accepted February 10, 2011

Published August 5, 2011

DOI http://dx.doi.org/10.4238/vol10-3gmr1177

\begin{abstract}
Serving as a DNA molecular weight standard, the DNA ladder has been widely used in molecular biology applications. We developed a simple method for the preparation of a DNA marker, which involves designing primers to amplify 100- to 1000-bp DNA fragments using lambda DNA as a template for polymerase chain reaction, followed by extraction with phenol/chloroform, precipitation with ethanol and mixing. Fragments of 100- to 1000-bp DNA were successfully amplified; the sequences showed $100 \%$ identity with lambda DNA. This prepared DNA marker displayed clear bands, indicating that it can be used for molecular studies.
\end{abstract}

Key words: DNA; Ladder; $\lambda$ DNA; Polymerase chain reaction 


\section{INTRODUCTION}

It is necessary to determine the molecular weight or the base pair length of nucleic acids in the field of molecular biology. Double-stranded DNA standards are typically prepared from DNA obtained from bacteriophages or plasmids (Wei et al., 2004; Zhu et al., 2005). This process is labor, material and equipment intensive, especially for the preparation of large quantities of DNA. Restriction enzyme-digested bacteriophage DNA such as lambda DNA is frequently employed for a set of molecular weight markers. The array of fragment lengths in bp obtained depends on the nature of the restriction enzyme, the DNA sequence, and the conditions employed. Each combination of restriction enzyme, DNA, and conditions will provide a unique array of DNA fragments of defined lengths (Hyman, 1998; Hu et al., 2005).

Polymerase chain reaction (PCR) has been widely applied in the fields of molecular biology, genetics, biochemistry, genetic engineering, forensics and the like. PCR is a simple, effective and convenient method and can be used to prepare adequate amounts of oligonucleotides in a very short time. A DNA ladder can be prepared based on the multiplex PCR technique (Wang et al., 2010). However, the intensity of each DNA fragment cannot easily be adjusted. In the present paper, we first amplified each DNA fragment and then mixed the DNA fragments according to their size to prepare the DNA ladder.

\section{MATERIAL AND METHODS}

\section{Chemicals}

$\lambda$ DNA and PCR Taq enzymes were all bought from Shanghai Sangon Company, China.

\section{PCR primers}

The primer design and sequences were according to those previously described by Wang et al. (2010).

\section{PCR amplification}

The amplifications were performed using the reaction mixture composition described as follows. A $0.5-\mu \mathrm{L}$ aliquot of the zero primer was added to each of ten 0.5 -mL microcentrifuge tubes. The tubes were numbered $1-10$, with tubes $1-10$ receiving $0.5 \mu \mathrm{L}$ of the 100 - to 1000 -bp primer solution, respectively. A stock solution was prepared consisting of $5 \mu \mathrm{L}$ lambda DNA (10 ng), $80 \mu \mathrm{L}$ dNTPs, $100 \mu \mathrm{L} 10 \mathrm{X}$ PCR buffer, $10 \mu \mathrm{L}$ Taq Polymerase (50 U) and $805 \mu \mathrm{L} \mathrm{H} \mathrm{O}_{2} \mathrm{O}$, with a final volume of $1000 \mu \mathrm{L}$. A $100-\mu \mathrm{L}$ volume of the stock mixture was added to each tube. PCR was performed under the following conditions: $95^{\circ} \mathrm{C}$ for $5 \mathrm{~min}$ followed by 30 cycles of $94^{\circ} \mathrm{C}$ for $40 \mathrm{~s}, 50^{\circ} \mathrm{C}$ for $30 \mathrm{~s}$ and $72^{\circ} \mathrm{C}$ for $40 \mathrm{~s}$, and finally $72^{\circ} \mathrm{C}$ for $10 \mathrm{~min}$.

\section{Preparation of DNA ladder}

A 5- $\mu \mathrm{L}$ aliquot of each PCR mixture was screened on $2 \%$ agarose gel electrophoresis, and the length was estimated by comparing with a known size DNA marker (Sangon), 
followed by purification and sequencing by the Sangon Company. BLAST was done at the NCBI server (http://blast.ncbi.nlm.nih.gov/Blast.cgi). The PCR products of each tube were extracted by phenol/chloroform and precipitated with ethanol, and they were then analyzed by UV absorbance at $260 \mathrm{~nm}$ and mixed thoroughly. A 5- $\mu \mathrm{L}$ aliquot of the prepared marker was electrophoresed, and the band migration pattern or band intensities were determined following ethidium bromide staining. The combined marker was frozen at $-20^{\circ} \mathrm{C}$.

\section{RESULTS AND DISCUSSION}

\section{PCR amplification}

The 10 DNA fragments of 100-1000 bp were amplified by PCR as described above. As shown in Figure 1, the bands of 100, 200, 300, 400, 500, 600, 700, 800, 900, and $1000 \mathrm{bp}$ were all evident on $2 \%$ agarose gels for tubes 1-10. After the PCR products were purified and sequenced, the amplified DNA lengths in tubes 1-10 were 100, 200, 300, 400, 500, 600, 700, 800,900 , and $1000 \mathrm{bp}$, respectively, and the target DNA sequences showed $100 \%$ identity with lambda DNA (data not shown).

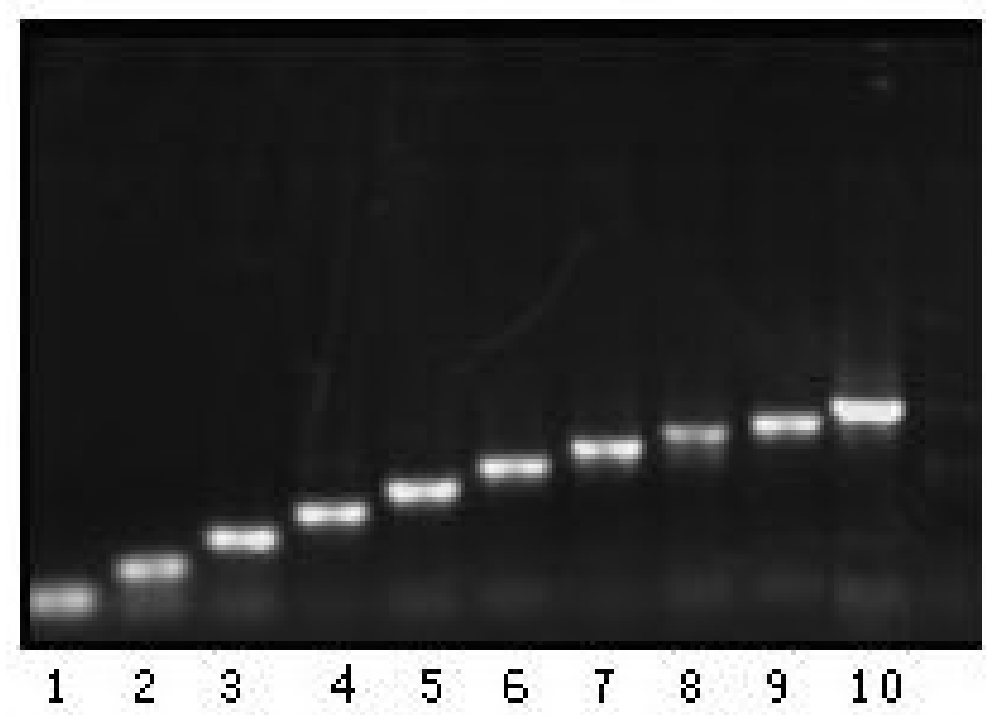

Figure 1. PCR amplification of 100- to 1000-bp DNA fragments. Lane $1=100 \mathrm{bp}$; lane $2=200 \mathrm{bp}$; lane $3=300$ bp; lane $4=400 \mathrm{bp}$; lane $5=500 \mathrm{bp}$; lane $6=600 \mathrm{bp}$; lane $7=700 \mathrm{bp}$; lane $8=800 \mathrm{bp}$; lane $9=900 \mathrm{bp}$; lane 10 $=1000 \mathrm{bp}$.

PCR is a very convenient technique in molecular biology and has been used in cloning DNA fragments. PCR products generally have lengths of 50 to $2500 \mathrm{bp}$. The template and primer are very important factors, which influence PCR results; good DNA template and primer can easily amplify the target DNA fragment. In our study, lambda DNA was chosen as PCR template; lambda DNA is 48,502 bp in length, and has been a good material to amplify target DNA fragments in some molecular studies. Primer design is also a very important step 
in the PCR process; the primers were designed with the Premier 5.0 software. From the PCR results, we could see that all five DNA fragments appeared in tubes 1-10 under the same reaction conditions, which are very simple and convenient.

\section{DNA ladder}

After purification and quantity analysis, the 100-, 200-, 300-, 400-, 500-, 600-, 700-, $800-, 900-$, and 1000-bp PCR products were thoroughly mixed, and then identified on $2 \%$ agarose gel electrophoresis (Figure 2). The intensities of the DNA fragments are proportional to the sizes of the fragments, since a small fragment has less mass of DNA at a given molar concentration. We used different amounts of DNA fragments to prepare the DNA ladder, so that the marker could easily be seen. The results showed that the prepared DNA marker bands were clear and could be seen under UV light.

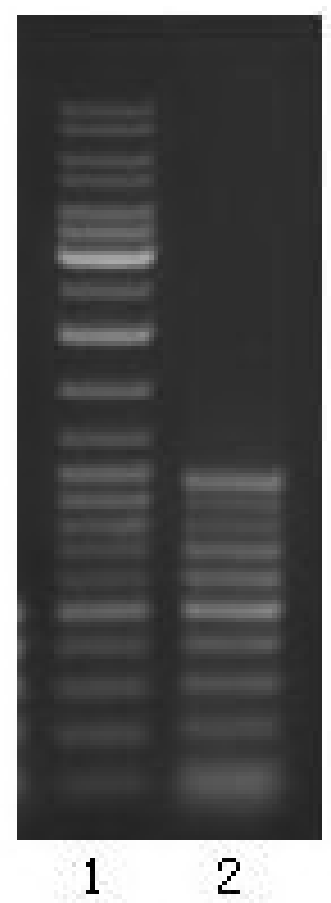

Figure 2. Agarose gel electrophoresis of the prepared DNA marker. A 5- $\mu \mathrm{L}$ aliquot of DNA marker prepared in the present study (lane 1) and Sangon Company (lane 2) were submitted to $2 \%(\mathrm{w} / \mathrm{v}$ ) agarose gel electrophoresis.

With the development of molecular biology, a DNA standard for determining DNA fragment length has been widely used in molecular experiments. The traditional standard is typically prepared from a bacteriophage or plasmid, where the digestion of the bacteriophage and plasmid, such as lambda DNA and pUC18, often generates many DNA fragments that are distributed irregularly. The digestion of lambda DNA with EcoRI will produce six DNA fragments: $21,226,4878,5643,7421,5804$, and $3530 \mathrm{bp}$ in length. Although the artificial vector, 
which contains special restriction enzyme sites was designed, the process was labor, material and equipment intensive, especially for the preparation of large quantities of DNA.

\section{CONCLUSION}

All 10 DNA fragments were easily amplified by the PCR method using lambda DNA as template, and the DNA marker could be prepared by mixing the purified PCR product thoroughly. We demonstrated that our prepared DNA marker was of good quality and could be used as a standard in molecular studies.

\section{ACKNOWLEDGMENTS}

Research supported in part by the National Natural Science Foundation of China (\#30970055) and the Natural Science Foundation of Henan Province, China (\#511042300, \#624410041).

\section{REFERENCES}

Hu ALW, Hartley JL and Jordan HJ (2005). Nucleic Acid Ladders. US Patent No. 6,924,098. Invitrogen Corporation, Carlsbad.

Hyman ED (1998). DNA Ladders. US Patent No. 5,840,575. United States Patent Office, Alexandria.

Wang TY, Guo L and Zhang JH (2010). Preparation of DNA ladder based on multiplex PCR technique. J. Nucleic Acids 2010. Doi 10.4061/2010/421803.

Wei LJ, Wei YT, Huang XF, Wei XQ, et al. (2004). Construction of a new kind of DNA marker vector. Biotechnology 14: 33-35.

Zhu CJ, Wei QY, Qu WL and Ding H (2005). Experimental study on making a new DNA marker from positive and negative DNA samples. Acta Med. Sin. 18: 937-938. 